\title{
HUBUNGAN ANTARA CURAH HUJAN DAN LUAS SERANGAN BELALANG KEMBARA (Locusta migratoria manilensis Meyen) DI PROVINSI LAMPUNG
}

\author{
Hamim Sudarsono, Rosma Hasibuan \& I Gede Swibawa \\ Jurusan Proteksi Tanaman Fakultas Pertanian Universitas Lampung \\ Jl. Sumantri Brojonegoro No. 1 Bandar Lampung 35145. \\ E-mail:hamim.sudarsono@gmail.com
}

\begin{abstract}
Relationship between rainfall intensity and area of damage caused by the migratory locust (Locusta migratoria manilensis Meyen) in Lampung Province. Population outbreak of the oriental migratory locust, Locusta migratoria manilensis Meyen (Orthoptera: Aciridae), in Lampung between 1990's to 2000's has caused serious economic loss to agriculture. Anticipation of the pest outbreak is required to prevent serious loss in the future; one of possible approach is by analyzing data of rainfall and locust damage area. The study was aimed to analyze the relationship between rainfalls and area of damage caused by locust population in rice and corn fields using 17 years period of data from Lampung Province. The results indicate that locust damage occurred when there were high rainfalls followed low ones at wet season. Time lag of 8 month was determined as the period needed for L. migratoria manilensis to raise its population when the pest has developed gregarious colonies in the region. Rainfalls between $248,27 \mathrm{~mm} / \mathrm{month}$ (on corn fields) to $287,06 \mathrm{~mm} / \mathrm{month}$ (on rice fields) were optimum for the initiation of the locust population increase after a period of dry weather in the region. Results of autocorrelation tests indicate that the occurrence of locust damage in an area would be followed by population increase in a region where gregarious colonies have developed.
\end{abstract}

Keywords: Locusta migratoria manilensis, rainfall, area of damage, time series analysis, time lag, autocorrelation.

\section{ABSTRAK}

Hubungan antara curah hujan dan luas serangan belalang kembara (Locusta migratoria manilensis Meyen) di Provinsi Lampung. Ledakan populasi belalang kembara, Locusta migratoria manilensis Meyen (Orthoptera: Acrididae) di Lampung antara tahun 1990 hingga 2000 menyebabkan kerugian ekonomi yang serius di bidang pertanian. Antisipasi ledakan populasi belalang kembara diperlukan untuk mencegah kehilangan hasil yang lebih besar di masa mendatang; salah satu pendekatan antisipasi yang memungkinkan adalah dengan menganalisis data curah hujan dan area kerusakan yang ditimbulkan oleh belalang kembara. Penelitian ini bertujuan untuk menganalisis hubungan antara curah hujan dan luas areal kerusakan akibat belalang kembara menggunakan data dengan rentang waktu 17 tahun dari Provinsi Lampung. Hasil analisis menunjukkan bahwa kerusakan oleh belalang kembara terjadi ketika pada suatu wilayah terdapat curah hujan tinggi yang diikuti dengan curah hujan rendah pada saat musim hujan. Tenggang waktu (time lag) yang diperlukan untuk meningkatkan populasi $L$. migratoria manilensis pada fase gregarius adalah 8 bulan. Curah hujan 248,27 mm/bulan (pada jagung) dan 287,06 mm/bulan (pada padi) merupakan curah hujan optimum untuk menginisiasi terjadinya peningkatan populasi belalang kembara setelah terjadinya periode kering di suatu wilayah. Hasil uji autokorelasi menunjukkan bahwa kerusakan akibat belalang kembara di suatu wilayah yang sudah memiliki populasi gregarius akan diikuti oleh peningkatan populasi hama ini.

Keywords: Locusta migratoria manilensis, curah hujan, luas areal kerusakan, analisis time series, time lag (tenggang waktu), autokorelasi.

\section{PENDAHULUAN}

Ledakan populasi (outbreak) belalang kembara (Locusta migratoria manilensis Meyen) (Orthoptera: Acrididae) yang terjadi antara tahun 1990-an hingga awal tahun 2000-an di Sumbagsel dan wilayah lain di Indonesia telah menimbulkan kerugian luar biasa (Kompas, 1998). Di Provinsi Lampung, puncak serangan belalang kembara pada tanaman pangan terjadi pada bulan Mei 1998 yang mencapai luas 6.818 ha pada lahan padi dan jagung yang tersebar di 43 kecamatan dari 83 kecamatan yang ada di Provinsi Lampung (51,8\%). Pada tanaman perkebunan, data dari Dinas Perkebunan Provinsi Lampung memperlihatkan bahwa serangan belalang pada tahun 1998 mencapai total luas serangan 9.213 ha dengan wilayah terparah pada lahan tebu PTPN di Sungkai Utara, Sungkai Selatan, dan Kotabumi (5.735 ha) diikuti oleh lahan tebu milik PT GMP seluas 2.163 ha di Menggala. Berdasarkan data di atas, secara nasional Provinsi Lampung termasuk salah satu wilayah 
yang paling parah mengalami eksplosi populasi hama belalang ini, terutama pada bulan April hingga Mei 1998.

Selain merusak komoditas pertanian di Lampung, hama belalang kembara juga merusak areal pertanian di beberapa wilayah lain di Indonesia seperti Kalimantan Barat, Kalimantan Tengah, Pulau Sumba, Timor, Flores, dan Jawa (Kompas, 1998b). Diduga di daerah-daerah tersebut telah terdapat sentra-sentra populasi belalang kembara yang setiap saat bisa menjadi wabah apabila faktor alam mendukung. Outbreak populasi belalang kembara seperti yang terjadi pada tahun 1998 tersebut sangat berpotensi untuk mengganggu ketahanan pangan di Indonesia sehingga diperlukan upaya antisipasi dan tindakan pengendalian yang berlandaskan perkembangan dan dinamika populasi belalang kembara.

Salah satu upaya untuk mengantisipasi terjadinya outbreak populasi belalang kembara ketika koloni gregarious sudah ditemukan pada suatu wilayah adalah dengan menganalisis bagaimana kondisi curah hujan di wilayah tersebut berpengaruh terhadap luas serangan belalang kembara. Penelitian sejenis ini telah dilakukan di beberapa negara yang sering mengalami outbreak populasi belalang kembara. Penelitian yang dilakasanakan di Mozambique dengan menggunakan analisis regresi logistik menunjukkan adanya hubungan yang kuat antara rerata curah hujan selama musim kemarau dengan keterjadian outbreak belalang kembara (Chiconela et al., 2003). Beberapa laporan penelitian juga telah mengonfirmasi bahwa salah satu faktor penting pemicu terjadinya ledakan populasi belalang kembara adalah kondisi iklim atau intensitas curah hujan di suatu wilayah. Belalang kembara umumnya berkembang biak dengan baik pada daerah tropika dengan iklim kering dan curah hujan tahunan kurang dari 1000 mm/tahun. Perkembangan optimum belalang kembara dilaporkan terjadi pada curah hujan 50-100 mm/bulan untuk fase soliter dan 25-100 mm/bulan untuk fase gregarious (Lecoq \& Sukirno, 1999). Faktor iklim seperti suhu, kelembaban relatif, curah hujan, dan kecepatan angin berpengaruh terhadap distribusi, perkembangan, ketahanan hidup, perilaku, serta dinamika populasi belalang kembara. Kondisi anomali iklim yang terjadi di Lampung selama beberapa tahun diduga telah memberikan kontribusi terhadap terjadinya ledakan populasi belalang kembara pada tahun 1998. Fenomena ledakan populasi belalang kembara di Lampung ini diawali dengan kondisi kemarau panjang dalam 10 tahun dengan curah hujan kurang dari 50\% dari kondisi normal (Balai Peramalan HPT Pangan dan Hortikultura, 1999).

Pada wilayah-wilayah yang sering mengalami ledakan populasi belalang kembara, hubungan antara curah hujan dan luas serangan belalang dapat dimanfaatkan untuk menduga 'tenggang waktu' (time lag) terjadinya lonjakan serangan serangan belalang kembara setelah terdapat hujan dengan intensitas yang memenuhi syarat untuk menimbulkan outbreak. Salah satu pendekatan yang bisa dilakukan adalah dengan analisis autokorelasi dan regresi silang dengan metode time series (Norusis, 2005). Berkenaan dengan hal ini, kami menyajikan hasil analisis tersebut berdasarkan data curah hujan dan luas serangan belalang kembara pada tanaman padi dan jagung selama beberapa tahun di Provinsi Lampung.

\section{METODE PENELITIAN}

Pelaksanaan. Penelitian ini dilaksanakan di Lampung dengan menggunakan data luas serangan belalang kembara pada beberapa komoditas tanaman pangan dan data curah hujan yang diperoleh dari beberapa instansi di Provinsi Lampung. Data luas serangan belalang kembara dan luas tanaman pangan diperoleh dari UPTD Balai Proteksi Tanaman Pangan, Dinas Pertanian Tanaman Pangan dan Hortikultura Provinsi Lampung, serta dari dinas-dinas pertanian di kabupaten yang ada di Lampung. Data curah hujan dikumpulkan dari berbagai sumber, terutama dari Badan Meteorologi dan Geofisika, Balai Proteksi Tanaman Pangan Provinsi Lampung, dan dari dokumentasi yang dikumpulkan oleh Balai Peralaman Hama dan Penyakit Tanaman Pangan dan Hortikultura.

Data curah hujan dan serangan belalang kembara yang terjadi di seluruh Provinsi Lampung sejak tahun 1990 hingga 2007 (rentang waktu 17 tahun) dianalisis dengan program Microsoft Excel 2007 dan SPSS versi 14.00. Kedua jenis data ini diperoleh dari Laporan Tahunan Balai Proteksi Tanaman Provinsi Lampung. Dua jenis analisis yang dilakukan dalam penelitian ini adalah: (1) Analisis untuk mendeskripsikan pola hubungan antara curah hujan dan luas serangan belalang dilakukan dengan plotting data tahunan dan bulanan kedua jenis data; dan (2) Analisis time series untuk menentukan time lag otimum yang bisa menjadi penduga periode waktu yang diperlukan oleh populasi belalang kembara untuk meningkat secara drastis jika kondisi curah hujannya sesuai.

Analisis Data. Data yang telah diperoleh dikelompokkan sesuai dengan jenisnya dan disusun berurutan berdasarkan bulan dan tahun. Setelah data ditabulasi selanjutnya dihitung jumlah dan rata-rata dari masing-masing data dilanjutkan dengan uji skewness untuk menguji normalitas data. Apabila data tidak tersebar normal maka data tersebut ditransformasi 
dengan $\log (\mathrm{x}+1)$. Analisis regresi time series untuk menduga time lag tertinggi dari lonjakan populasi belalang kembara dilakukan dengan menggunakan software SPSS versi 14.0 (SPSS Inc., 2005). Dari analisis ini diperoleh nilai korelasi silang dan autokorelasi parsial dari data luas serangan belalang kembara (Norusis, 2005). Analisis regresi ini juga digunakan untuk mengetahui seberapa besar hubungan antara curah hujan dan luas serangan serta antara luas serangan pada bulan tertentu dengan luas serangan belalang kembara pada bulan-bulan berikutnya. Persamaan regresi diuji dengan menggunakan uji $\mathrm{F}$ (uji linieritas menyeluruh), sedangkan uji untuk koefisien individunya digunakan uji t pada taraf nyata $5 \%$. Kontribusi X (curah hujan) terhadap Y (luas serangan belalang kembara) dihitung dengan koefisien determinasi $\left(\mathrm{R}^{2}\right)$.

\section{HASIL DAN PEMBAHASAN}

Hubungan antara Curah Hujan dan Luas Serangan. Hasil plotting antara data curah hujan dan luas serangan untuk rentang waktu 17 tahun (1990 - 2007) menunjukkan adanya hubungan yang kuat antara pola curah hujan dan luas serangan belalang kembara di Provinsi Lampung. Fluktuasi dua komponen data tersebut menunjukkan adanya pengaruh dari intensitas curah hujan terhadap luas serangan belalang kembara pada dua tanaman pangan utama di Lampung yang juga sekaligus merupakan makanan utama dari belalang kembara, yaitu padi sawah dan jagung. Dari pola fluktuasi ini diketahui bahwa puncak luas serangan belalang kembara pada tanaman padi sawah dan jagung terjadi pada tahun 1998 yang masing-masing mencapai sekitar 10.000 ha (Gambar 1). Terlihat juga bahwa luas dan fluktuasi serangan belalang kembara pada kedua komoditas ini sangat mirip. Diduga kemiripan ini berkaitan dengan fakta bahwa padi dan jagung merupakan dua jenis tanaman dari famili Gramineae yang paling disukai oleh hama belalang kembara (Kalshoven, 1984).

Untuk mempertegas hasil plotting di atas, dalam analisis ini juga dilakukan plotting antara curah hujan bulanan dan luas serangan bulanan pada periode yang diperkirakan terdapat populasi belalang kembara gregarius di Lampung, yaitu antara tahun 1995 hingga 2001. Hasil plotting dari periode ini juga menunjukkan adanya pola yang konsisten. Peningkatan luas serangan belalang kembara pada tanaman padi dan jagung di Lampung terjadi setelah selama beberapa bulan daerah ini mengalami curah hujan yang rendah. Tingkat curah hujan rendah yang terjadi pada bulan September kemudian memicu terjadinya peningkatan populasi belalang kembara pada bulan November - Januari. Yang perlu diperhatikan dari pola fluktuasi ini adalah adanya tenggang waktu antara terjadinya curah hujan yang tinggi dengan meningkatnya luas serangan belalang kembara. Tenggang waktu ini tampak jelas pada tahun 1998 (Gambar 2). Kondisi ini sejalan dengan beberapa hasil

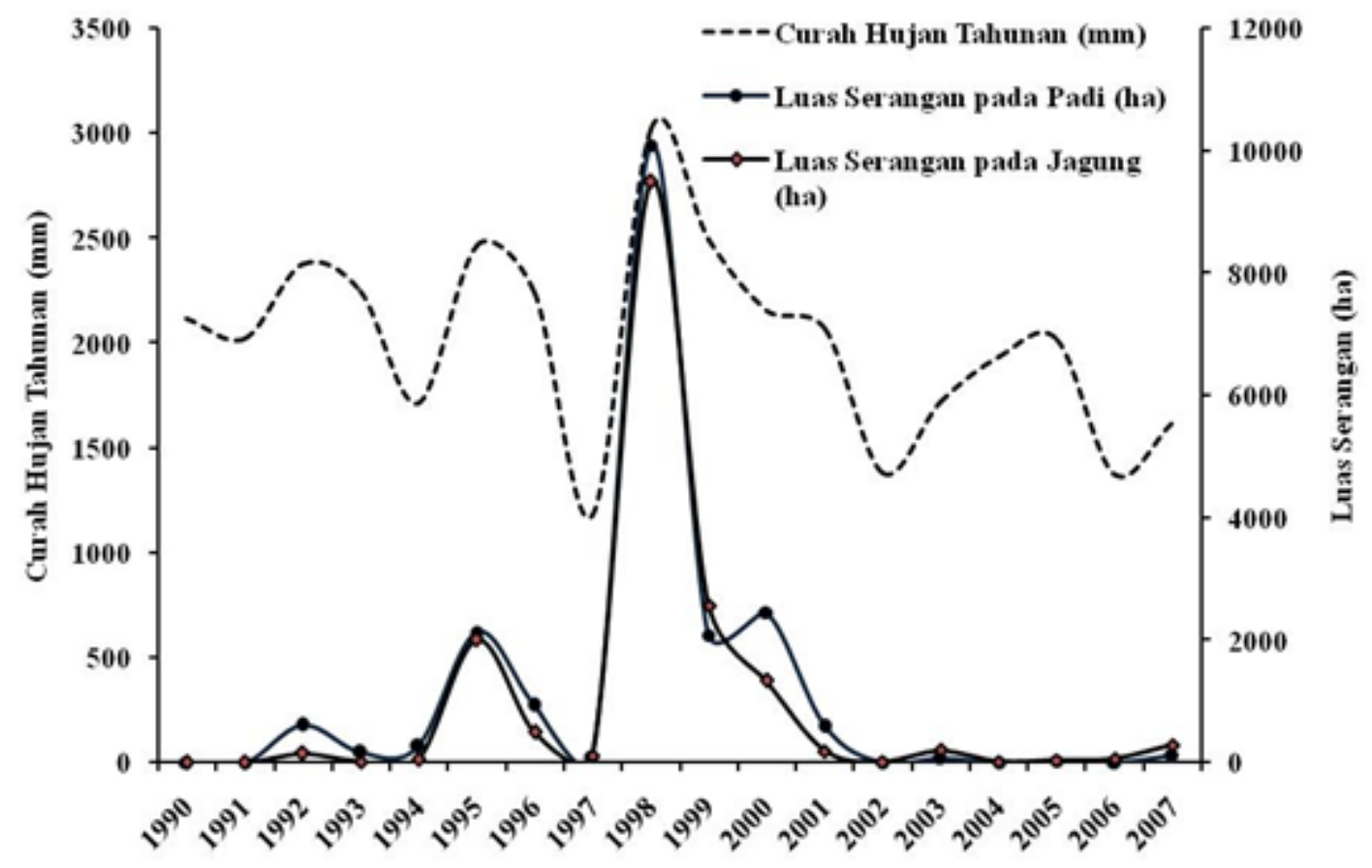

Gambar 1. Hasil plotting data curah hujan dan luas serangan belalang kembara pada komoditas padi dan jagung dari tahun 1990 hingga 2007 di Provinsi Lampung. 


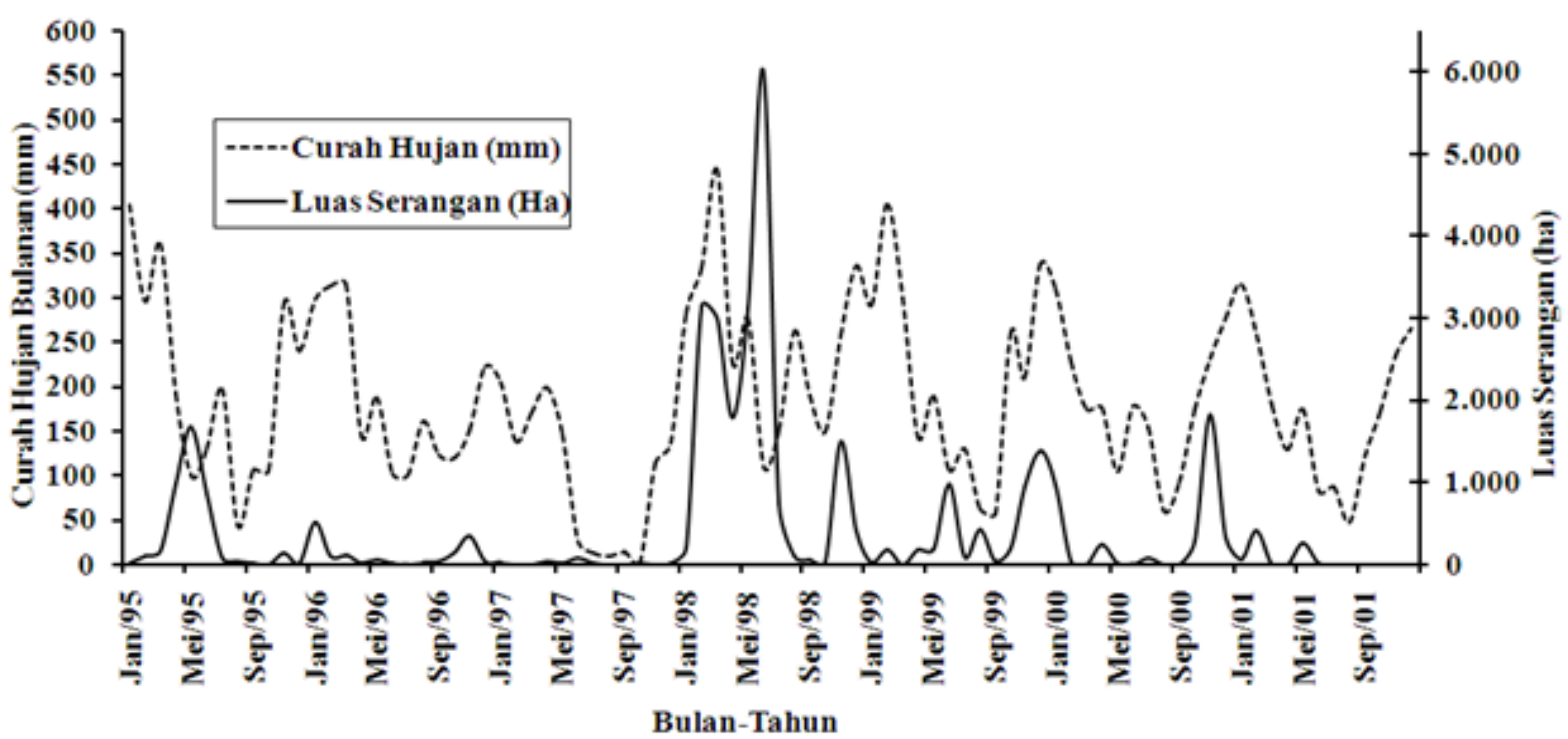

Gambar 2. Pola hubungan antara curah hujan bulanan dan luas serangan belalang kembara pada periode outbreak di Provinsi Lampung (1999 - 2001).

penelitian lain yang menyimpulkan bahwa peningkatan populasi belalang kembara sering kali terjadi apabila ada curah hujan yang cukup setelah terdapat rentang waktu panjang tanpa hujan (Chiconela et al., 2003; Anonim, 2010).

Serangan belalang kembara pada tahun 1998 yang terjadi di Lampung didahului oleh kondisi musim kemarau panjang selama beberapa tahun sebelumnya. Gambaran pada kurva ini sesuai dengan rekaman curah hujan Lampung yang menunjukkan bahwa dalam kurun waktu 10 tahun (1989 - 1998) daerah ini memiliki curah hujan sangat rendah atau kurang dari 50\% kondisi normal. Pada periode tersebut, Lampung mengalami curah hujan bulanan $33-234 \mathrm{~mm} /$ bulan dengan jumlah curah hujan tahunan $1.223 \mathrm{~mm}$; sementara dalam kondisi normal Lampung memiliki curah hujan bulanan 96-275 mm/bulan dan curah hujan tahunan $2.163 \mathrm{~mm} /$ tahun. Setelah terjadinya eksplosi pada tahun 1998 populasi belalang kembara pada bulan-bulan berikutnya menurun dan akhirnya serangan belalang menjadi normal atau tidak terlihat lagi. Diduga pada saat itu populasi belalang kembara telah mencapai keseimbangan dalam fase soliter atau sebagian telah dikendalikan. Selain itu, ketersediaan makanan diduga juga mempengaruhi perkembangan belalang kembara pada hamparan karena masa setelah panen adalah masa bera sehingga pada saat itu tidak terdapat tanaman (padi dan jagung) yang merupakan tanaman kesukaan belalang. Kemungkinan lainnya, pada periode tersebut gerombolan belalang kemungkinan berpindah ke tempat lain mencari makan/ inang alternatifnya atau kemudian secara berangsur kembali berada dalam fase soliter. Sebagaimana diketahui, belalang kembara akan berubah dari fase gregarius menjadi fase soliter ketika kepadatan individunya telah menurun dan berada di bawah ambang gregarisasinya (Luong-Skovmand, 1999).

Analisis Regresi: Curah Hujan Vs. Luas Serangan. Hasil analisis korelasi analisis regresi antara curah hujan pada time lag 8 bulan (X) dengan luas serangan belalang kembara (Y) pada tanaman padi sawah dan jagung (Gambar 3) di Provinsi Lampung menghasilkan model regresi dengan persamaan sebagai berikut:

(1) Pada padi: $Y=3,0382-0,0182 X+3,17^{*}\left(10^{-5} \mathrm{X}^{2}\right)$

Keterangan:

$\mathrm{Y}=$ luas serangan (ha);

$\mathrm{X}=$ curah hujan $(\mathrm{mm})$;

$\mathrm{R}^{2}=0,5830(\mathrm{P}<0,0001)$

(2) Pada jagung: $\mathrm{Y}=2,9230-0,0216 \mathrm{X}+4,35 * 10^{-5} \mathrm{X}^{2}$

Keterangan:

$\mathrm{Y}=$ luas serangan (ha);

$\mathrm{X}=$ curah hujan (mm);

$\mathrm{R}^{2}=0,5751(\mathrm{P}<0,0001)$. 


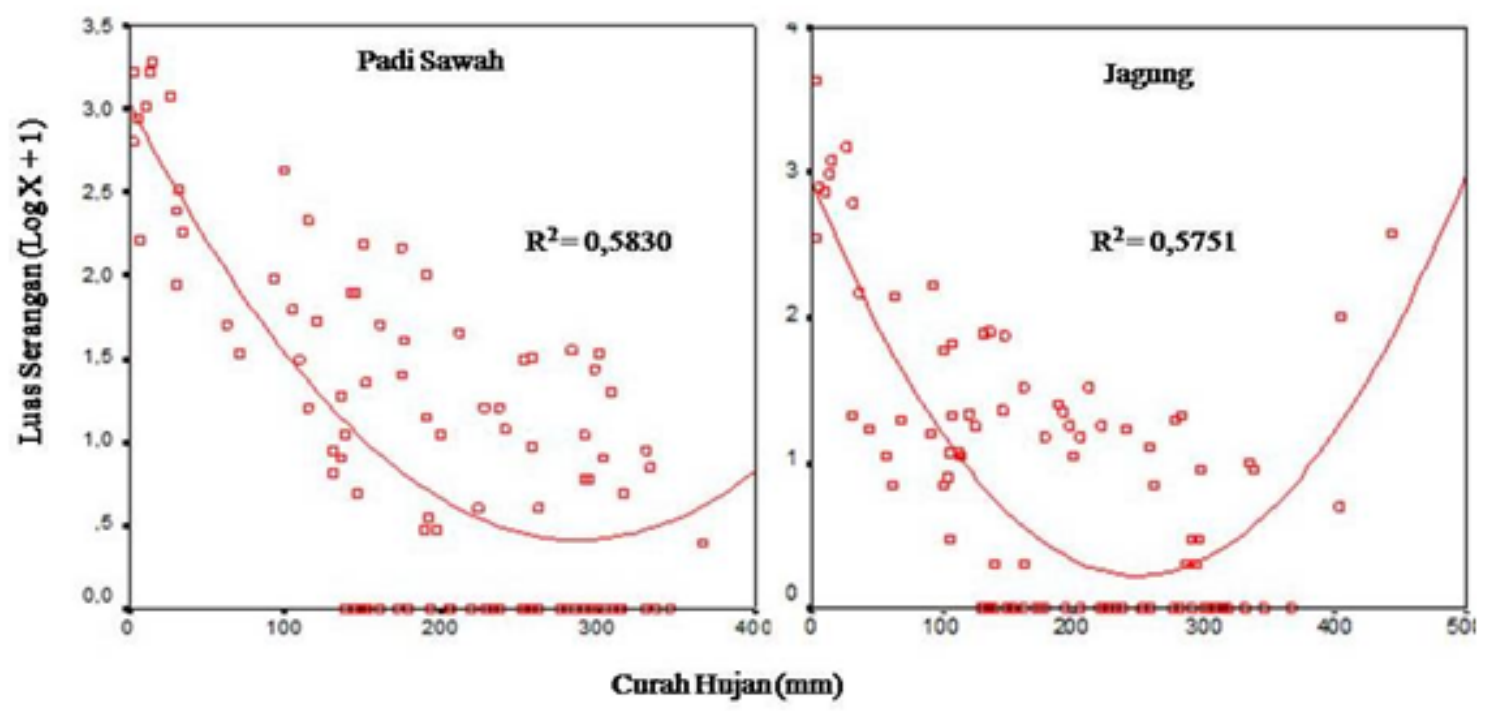

Gambar 3. Diagram pencar hubungan antara rata-rata curah hujan (X) dan luas serangan (Y) belalang kembara pada tanaman padi sawah.

Kedua model regresi diatas menunjukkan adanya hubungan kuadratik antara curah hujan pada time lag 8 bulan dengan luas serangan belalang kembara. Pada komoditas padi, nilai koefisien determinasi $\left(\mathrm{R}^{2}\right)=0,5830$ menunjukkan bahwa kontribusi curah hujan untuk menyebabkan terjadinya serangan belalang kembara adalah sebesar 58,30 \% $(\mathrm{P}<0,0001)$. Curah hujan optimum bagi perkembangan belalang kembara pada habitat tanaman padi adalah sebesar 287,06 mm/bulan. Berdasarkan diagram ini maka dapat diprediksi bahwa apabila pada suatu bulan tertentu suatu wilayah mengalami curah hujan sekitar 287,06 mm/bulan maka dapat diharapkan akan terjadi peningkatan luas serangan belalang kembara pada waktu delapan bulan yang akan datang. Pendugaan ini berlaku apabila berdasarkan pemantauan selama beberapa bulan terakhir di suatu wilayah telah terdapat populasi belalang kembara dalam fase gregarius. Pada hamparan yang tidak memiliki populasi gregarius, prediksi ini kemungkinan tidak berlaku mengingat bahwa peningkatan luas serangan belalang kembara dapat terjadi apabila di wilayah tersebut telah terdapat akumulasi deposit kelompok telur belalang kembara yang tersimpan di bawah permukaan tanah pertanian. Sebagaimana ditunjukkan oleh hasil penelitian Sudarsono (2008), telur belalang kembara yang berada di dalam tanah dapat bertahan selama 21 - 105 hari pada kondisi tanpa hujan atau intensitas curah hujan rendah. Ada kemungkinan telur belalang dapat bertahan lebih lama apabila periode kering berlangsung lama yang sekaligus juga menyebabkan jumlah terlur yang teakumulasi semakin banyak. Akumulasi kelompok telur ini akan menetas dalam waktu 14 - 15 hari apabila terdapat curah hujan yang sesuai.
Seperti hasil analisis pada tanaman padi, hasil analisis juga menunjukkan adanya hubungan kuadratik antara curah hujan pada time lag 8 bulan dan luas serangan belalang kembara pada habitat tanaman jagung. Nilai koefisien determinasi $\left(\mathrm{R}^{2}\right)=0,5751$ menunjukkan bahwa kontribusi curah hujan untuk menyebabkan terjadinya serangan belalang kembara adalah sebesar $57,51 \%(P<0,0001)$. Curah hujan optimum bagi perkembangan belalang kembara pada habitat tanaman jagung adalah sebesar 248,27 mm/bulan (Gambar 3).

\section{Analisis Autokorelasi Parsial Data Luas Serangan.}

Hasil analisis autokorelasi parsial antarluas serangan belalang kembara pada tanaman padi maupun jagung menunjukkan bahwa luas serangan awal pada time lag 1 bulan paling berkorelasi dengan luas serangan belalang kembara pada bulan-bulan berikutnya. Luas serangan awal pada time lag 1 bulan berada di atas limit konfidensi dengan nilai koefisien korelasi $(\mathrm{r})=0,732$ (padi sawah) dan 0,413 (jagung). Luas serangan awal pada time lag 1 bulan diikuti dengan peningkatan serangan belalang kembara pada beberapa bulan berikutnya (Gambar 4). Selanjutnya, analisis regresi antara luas serangan awal pada time lag 1 bulan dengan luas serangan belalang kembara pada tanaman padi dan jagung di Provinsi Lampung menghasilkan model linier (Gambar 5) dengan persamaan sebagai berikut:

(1) Pada padi: $\mathrm{Y}=0,1039+0,8645 \mathrm{X}$

Keterangan:

$\mathrm{Y}=$ Luas serangan belalang kembara yang akan datang

$\mathrm{X}=$ Luas serangan awal pada lag 1 bulan

$r=0,876 ; R^{2}=0,7678(P<0,0001)$ 


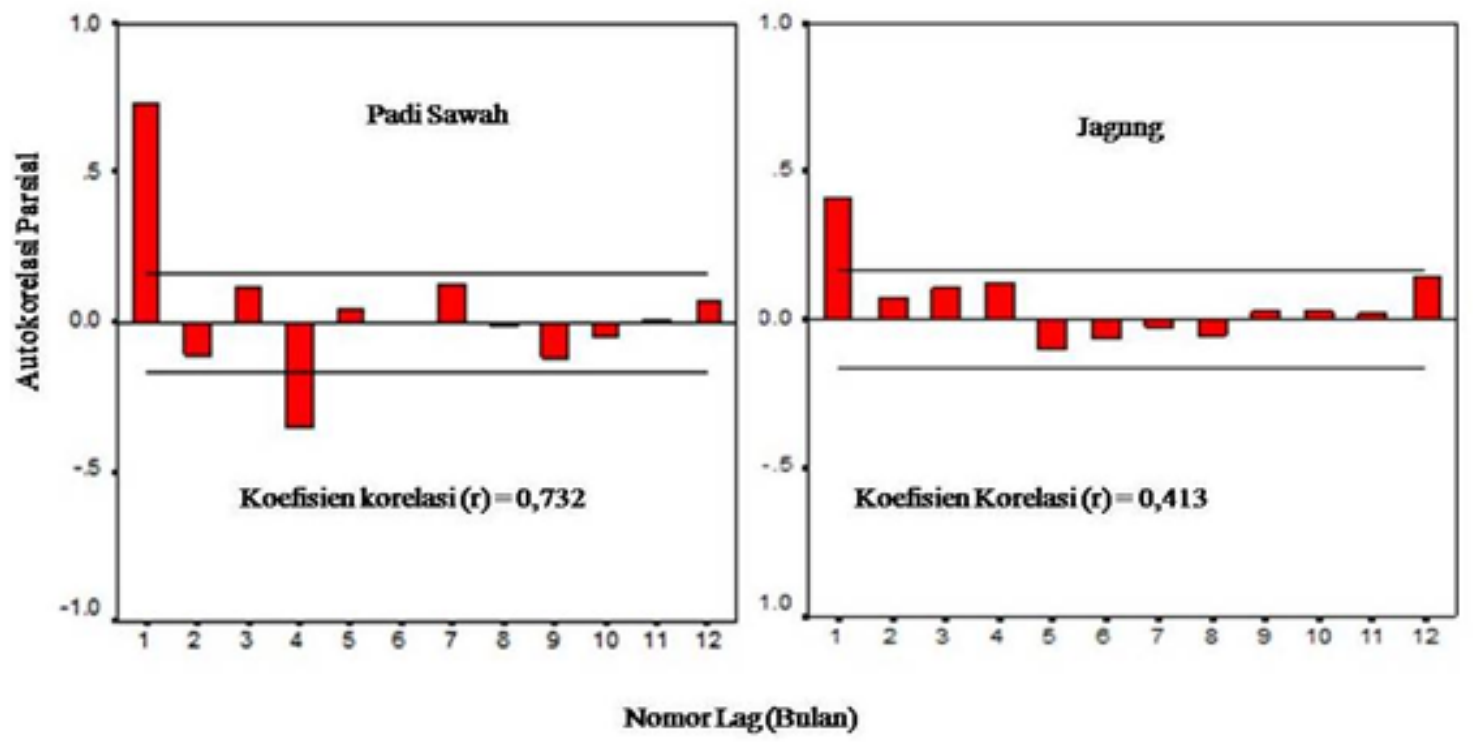

Gambar 4. Koefisien autokorelasi parsial antarluas serangan belalang kembara pada habitat tanaman padi sawah dan jagung di Provinsi Lampung.
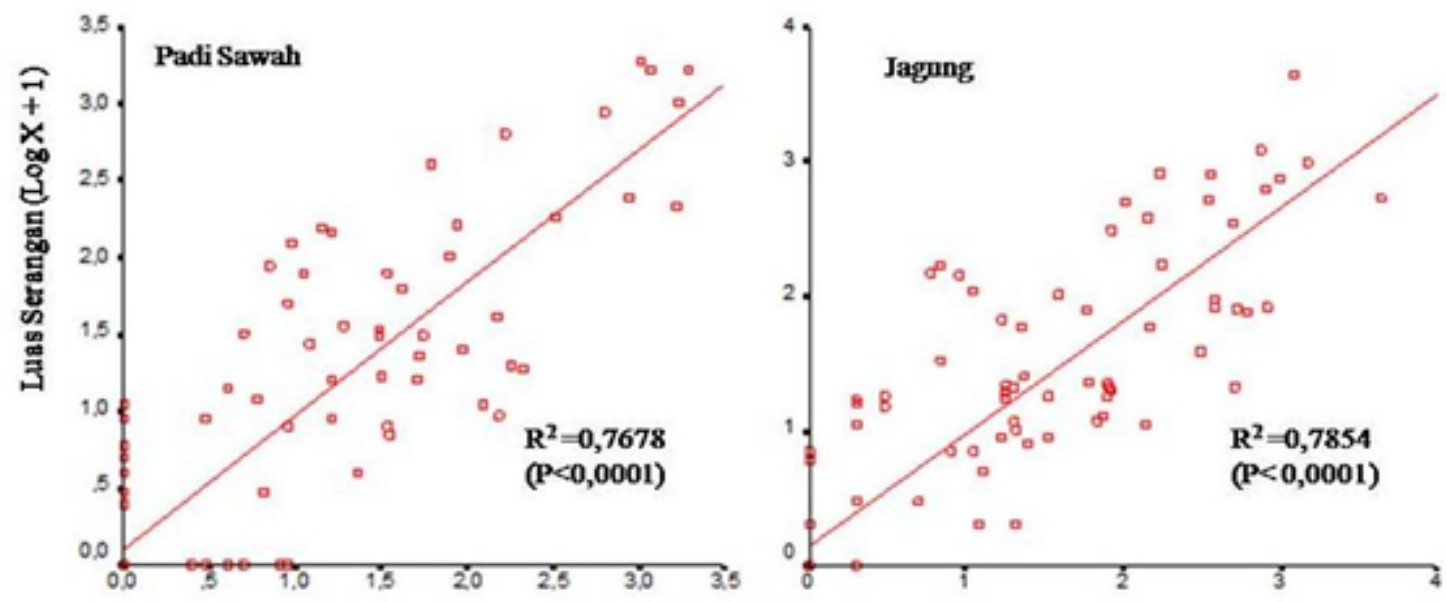

\section{Luas Serangan padaLag 1 Bulan $(\log X+1)$}

Gambar 5. Hubungan antara luas serangan awal pada time lag 1 bulan (X) dengan luas serangan belalang kembara (Y) pada tanaman jagung.

(2) Pada tanaman jagung: $\mathrm{Y}=0,1422+0,8381 \mathrm{X}$

Keterangan :

$\mathrm{Y}=$ Luas serangan belalang kembara yang akan datang

$\mathrm{X}=$ Luas serangan awal pada lag 1 bulan

$\mathrm{r}=0,8862 ; \mathrm{R}^{2}=0,7854(\mathrm{P}<0,0001)$

Hasil regresi di atas memperlihatkan bahwa suatu wilayah yang memiliki populasi belalang kembara fase gregarius maka perkembangan populasi belalang ini bisa berlangsung sangat cepat. Kondisi inilah yang kemungkinan menyebabkan beberapa wilayah di Lampung mengalami outbreak populasi belalang kembara pada akhir tahun 1990-an. Berdasarkan hasil analisis ini, waktu yang diperlukan untuk terjadinya outbreak belalang kembara adalah satu bulan apabila populasi yang ada sudah berada dalam fase gregarius. Diduga, kondisi terjadinya outbreak dengan tenggang waktu satu bulan ini memerlukan prasyarat-prasyarat lain yang masih perlu diteliti lebih lanjut.

\section{SIMPULAN}

Terdapat hubungan yang kuat antara pola curah hujan dan luas serangan belalang kembara di Provinsi Lampung, baik pada tanaman padi maupun tanaman jagung. Peningkatan luas serangan belalang kembara pada kedua komoditas pangan utama ini terjadi setelah 
Lampung selama beberapa bulan mengalami curah hujan yang rendah. Terdapat tenggang waktu (time lag) antara terjadinya curah hujan yang tinggi dengan meningkatnya luas serangan belalang kembara; hal ini menunjukkan bahwa peningkatan populasi belalang kembara terjadi apabila ada curah hujan yang cukup setelah terdapat rentang waktu panjang tanpa hujan. Serangan belalang kembara pada suatu bulan tertentu dipengaruhi oleh curah hujan yang terjadi pada 8 bulan sebelumnya (time lag 8 bulan). Curah hujan antara 248,27 mm/bulan (pada tanaman jagung) hingga 287,06 $\mathrm{mm} /$ bulan (pada tanaman padi) yang terjadi setelah periode kering diduga dapat meningkatkan luas serangan belalang kembara apabila di suatu wilayah telah terjadi akumulasi deposit telur belalang kembara di dalam tanah. Pada saat suatu wilayah memiliki populasi belalang kembara yang berada dalam fase gregarius, perkembangan populasinya bisa berlangsung sangat cepat (regresi linier).

\section{SANWACANA}

Penelitian ini merupakan bagian dari rangkaian penelitian yang memperoleh pendanaan dari Proyek RUT dan dilanjutkan dengan Hibah Strategis 2009. Tim peneliti mengucapkan terima kasih kepada LIPI dan Kemendiknas RI yang telah memberikan pendanaan tersebut. Tim peneliti juga berterimakasih kepada Sdr. Endang Saptriyani, alumni Jurusan Proteksi Tanaman Fakultas Pertanian Universitas Lampung, yang telah berpartisipasi dalam bentuk penelitian skripsi pada bagian-bagian awal dari proyek ini.

\section{DAFTAR PUSTAKA}

Anonim. 2010. Weather has slowed down locust activity in Victoria, but reports of recent crop damage are coming in. WEEKLY TIME NOW, December 7, 2010, http:// www.weeklytimesnow.com.au/article/2010/12/ 07/270055_latest-news.html. Diakses: 26 April 2011.

Balai Peramalan HPT Pangan dan Hortikultura. 1999. Pengembangan Model Peramalan Belalang Kembara pada Tanaman Pangan di Lampung dengan Pemanfaatan Sistem Informasi Geografis. Laporan. 46 hlm.

Chiconela T, Chongo D, D'uambal P, Ngazero A, \& Santos L. 2003. Predicting the occurrence of red locust outbreaks in Mozambique. African
Crop Science Conference Proceedings, Vol. 6: pp224-230.

Hunter DM, Walker PW, \& Elder RJ. 2001. Adaptation of locusts and grashoppers to the low and variable rainfall of Australia. J. Orthoptera Res. 10 (2):347-351.

Kompas. 1998. Serangan Belalang Mengganas. Harian Kompas, 4 Mei 1998.

Kompas. 1998b. Belalang Serang Lima Provinsi. Harian Kompas, 4 Mei 1998.

Luong-Skovmand. 1999. Biology of the oriental migratory locust. Unpublished paper presented in "Seminar for technology transfer of locust survey and control”. Lampung, 12-16 July 1999. 43 pp.

Norusis MJ. 2005. SPSS 14.0 Advanced Statistical Procedures Companion. Prentice Hall, Chiicago. 366 pp.

SPSS Inc. 2005. SPSS for Windows SPSS ${ }^{\circledR}$ Version 14.0. Chicago.

Stige LK, Zhang CZ, Frank D, \& Stenseth N. 2007. Thousand-year-long Chinese time series reveals climatic forcing of decadal locust dynamics. Proceedings of the National Academy of Sciences of the USA 104 (41): 161-188. Retrieved May 10, 2011, from ProQuest Agriculture Journals. (Document ID: 1366981901).

Sudarsono H. 2003. Hama Belalang Kembara (Locusta migratoria manilensis): Fakta dan Analisis Awal Ledakan Populasi di Lampung. JHPTT 3 (2):51-56.

Sudarsono H. 2008. Pengaruh lama periode kering dan intensitas curah hujan terhadap penetasan belalang kembara (Locusta migratoria manilensis Meyen). JHPTT 8 (2):117 - 122.

Sudarsono H, Hasibuan R, \& Buchorie D. 2005. Biologi dan Transformasi Belalang Kembara Locusta migratoria manilensis Meyen (Orthoptera: Acrididae) pada Beberapa Tingkat Kepadatan Populasi di Laboratorium. JHPTT 5 (2):24-31. 